\title{
Analysis on Priority Order and Influencing Factors of Forest Farmers Demand for Forest Reform Policy - A Case Study in Jiangxi, China
}

\author{
Hui Xiao", Fangting Xie ${ }^{2}$, Shubin $\mathrm{Zhu}^{2,}$, , Caiwang Ning ${ }^{1}$ \\ ${ }^{1}$ Department of Economics and Management, Jiangxi Agricultural University, Nanchang, China \\ ${ }^{2}$ Institute of Rural Development, Jiangxi Agricultural University, Nanchang, China
}

Email address:

shubinzhu@163.com (Shubin Zhu)

${ }^{*}$ Corresponding author

To cite this article:

Hui Xiao, Fangting Xie, Shubin Zhu, Caiwang Ning. Analysis on Priority Order and Influencing Factors of Forest Farmers Demand for Forest Reform Policy - A Case Study in Jiangxi, China. Humanities and Social Sciences. Vol. 7, No. 5, 2019, pp. 164-170.

doi: $10.11648 /$ j.hss.20190705.14

Received: September 7, 2019; Accepted: September 27, 2019; Published: October 15, 2019

\begin{abstract}
This paper analyzed forest farmers' priority demands for forest reform policies through average linkage clustering analysis and multinomial logistic regression model by applying survey data of 500 households in Jiangxi province. The results indicated that the subsidy policies is the most needed policies followed by the forestry science and technology service policy, and financial services. In addition multinomial logistic regression model analysis was used to study what factors influence farmers'priority demand for forest reform policies. The empirical results show that the age of head of household, the area of household forest land, whether forest farmers have participated in forest right mortgage loans and forest insurance significantly affect the demand of forest farmers for forest reform policy. Finally, some pertinent suggestions were put forward to promote the collective forest reform.
\end{abstract}

Keywords: Forest Reform Policies, Demand Priority, Influencing Factors

\section{Introduction}

In 2003, the reform of collective forest ownership system took the lead in Jiangxi, Fujian, Liaoning and Zhejiang provinces. In 2009 the reform swept across the whole country. The implementation of the reform of collective forest ownership system enriches the connotation of the household contract management system. It is regarded as the third agrarian reform. In 2008, the publication of the document "opinions of the State Council of the CPC (Communist Party of China) Central Committee on comprehensively promoting the Reform of Collective Forest ownership system" indicated that the reform of the collective forest right system in China has been basically completed, and the supporting reform measures are being carried out step by step [1]. In this regard, domestic scholars concentrate on the "clear property rights, reduce taxes and fees, let live management, regulate circulation" basic policy launched in-depth research. The reform policy of forest ownership system further clarified the property right [2], aroused the enthusiasm of forestry production of the vast number of forest farmers, effectively increased the forest area and storage quantity, raised the income level of forest farmers [3-5], and promoted the development of forestry productivity [6]. Initial positive results have been achieved in the reform. But at the same time, the reform also brought some negative consequences, for example, the reform of collective forest rights system led to the aggravation of forest land fragmentation [7], and the degree of forest land fragmentation had a significant negative impact on forest land output of forest farmers families. Therefore, the comprehensive reform of forest area and the establishment of perfect public finance system should be actively promoted [8]. According to the existing literature research, the current research mainly focuses on the effect of forest reform policy supply, and few documents evaluate the demand and the level of demand of forest farmers for forest reform policy. Based on this, this paper will evaluate the priority order of forest farmers undefined demand for forest reform policy from the point of view of individual forest 
farmers, and further analyze its influencing factors and the degree of influence, so as to put forward the direction of deepening the reform of collective forest tenure system in the future.

\section{Data Source and Sample Description}

\subsection{Data Sources}

In order to further monitor and study the effectiveness of the reform of collective forest ownership system, we conducted an investigation of 500 sample households in Jiangxi Province in August 2018. The sampling method was as follows: First, 10 counties were selected according to the level of economic development and the distribution of forest resources, i.e. Dexing County, Wuning County, Yifeng County, Yongfeng County, Lian County, Qianshan, Suichuan County, Lichuan County, Xinfeng County and Chongyi County; then, five sample villages were selected from each county, and 10 sample households were selected from the sample village by random sampling method according to the household registration list. In each sample household, trained interviewers made a face-to-face interview with the household head. In total, 500 questionnaires were acquired.

\subsection{Sample Definition and Description}

\subsubsection{Characteristics of Household of Forest Farmers}

In the sample, most of the heads of household were male, and the age of the head of household was concentrated in 51 $\sim 60$ years old and over 60 years old, accounting for $71.4 \%$ of the total, only $4.2 \%$ of the household head under 40 years old, $33.4 \%$ of them over 60 years old, and the age structure of rural labor force was unbalanced. $35.8 \%$ of the householders were with primary school education, $42.6 \%$ of the householders were with junior middle school education, only $18 \%$ of the householders were with high school education and university or above Among the occupations headed by forest farmers, $41 \%$ of them are mainly engaged in agriculture, and $20.2 \%$ of them are part-time workers.

Table 1. Characteristics of household of forest farmers.

\begin{tabular}{llll}
\hline Characteristic description & & Number/n & Percentage/\% \\
\hline \multirow{2}{*}{ sex } & Female & 28 & $5.6 \%$ \\
& Male & 472 & $94.4 \%$ \\
& 30 years old or below & 1 & $0.2 \%$ \\
age & 31 40 years old & 20 & $4 \%$ \\
& $41 \sim 50$ years old & 122 & $24.4 \%$ \\
& $51 \sim 60$ years old & 190 & $38 \%$ \\
& 60 years old or above & 167 & $33.4 \%$ \\
\multirow{2}{*}{ Education } & Primary school or below & 179 & $35.8 \%$ \\
& Middle school & 213 & $42.6 \%$ \\
& High school & 90 & $18 \%$ \\
occupation & University or above & 18 & $3.6 \%$ \\
& Focus on farming & 205 & $41 \%$ \\
\hline
\end{tabular}

\subsubsection{Characteristics of Forest Farmer Resources}

Of the family members of forest farmers, $188(37.6 \%)$ have been cadres or have been cadres. There were 230 households (46\%) with more than 5 plots, $68.8 \%$ with forest land area below $6.73 \mathrm{hm} 2$, and only a small number of forest plots with more than 10 plots or forest land area above $13.3 \mathrm{hm} 2$. The traditional household small-scale management was the main management mode of forest land, and the forest land was finer and shredded than the big-scale. (Table 2).

Table 2. Characteristics of forest farmers.

\begin{tabular}{|c|c|c|c|}
\hline Characteristics of forest farmers & description & Number/n & Percentage $/ \%$ \\
\hline \multirow{2}{*}{ Whether the family members ever served as village cadres } & Yes & 188 & 37.6 \\
\hline & No & 312 & 62.4 \\
\hline \multirow{2}{*}{ Number of family woodland blocks } & $1 \sim 4$ & 270 & 54 \\
\hline & 10 or above & 35 & 7 \\
\hline \multirow{3}{*}{ Household forest land area } & $1.33 \mathrm{hm} 2$ or below & 153 & 30.6 \\
\hline & $1.4 \sim 6.73 \mathrm{hm} 2$ & 191 & 38.2 \\
\hline & $13.3 \mathrm{hm} 2$ or above & 81 & 16.2 \\
\hline
\end{tabular}

\subsubsection{Characteristics of Forest Farmers Behavior}

Since the reform of the collective forest right system, the property right of the forest land has been further clarified. By the end of 2011, the license-issuing rate of the forest land in Jiangxi Province has already accomplished. Compared to the reform of the main body, the progress of the supporting reform policy was slow, the forestry co-operation organization or the forest farmer participating in the joint contract only accounts for about $10 \%$ of the sample, and the forest farm of the forest right mortgage loan was less than 3\% through the forest right certificate, and the reform has not achieved the due effect. In 
the field investigation, it was found that the public welfare forest was in charge of the forest insurance in the province or the county, but many of the forest farmers had no knowledge of it, and the forest farmers who participated in the forest insurance account for $25.8 \%$ of the sample; After the forest land contracted to the household, the enthusiasm of forest farmers to plant trees was high, and more than $87 \%$ of forest farmers carried out forest construction behavior.

Table 3. Behavior characteristics of forest farmers.

\begin{tabular}{|c|c|c|c|}
\hline Behavior characteristics of forest farmers & Response result & Number/n & Percentage $/ \%$ \\
\hline \multirow{2}{*}{ Whether to join the Forestry Cooperation Organization } & Yes & 47 & 9.4 \\
\hline & No & 453 & 90.6 \\
\hline Whether to participate in joint contracting & Yes & 350 & 70 \\
\hline \multirow{2}{*}{ Whether occurred a dispute over the right of forestland } & Yes & 44 & 8.8 \\
\hline & No & 456 & 91.2 \\
\hline Whether occurred forestland transfer & Yes & 96 & 19.2 \\
\hline \multirow{2}{*}{ Whether a mortgage for forest rights } & Yes & 10 & 2 \\
\hline & No & 490 & 98 \\
\hline \multirow{2}{*}{ Whether or not to participate in forest insurance } & Yes & 129 & 25.8 \\
\hline & No & 371 & 74.2 \\
\hline \multirow{2}{*}{ Whether to create a forest } & Yes & 447 & 89.4 \\
\hline & No & 53 & 10.6 \\
\hline
\end{tabular}

\section{The Analysis of the Priority of Forest-to-Forest Policy Demand}

In order to know the priority order of forest farmers demand for forest reform policy, 13 items of forest reform policy were listed in the questionnaire, and the forest farmers were asked to prioritize the demand of forest reform policy according to the actual situation, the most needed policy choice was labeled by 1 , the second needed policy choice was labeled by 2 , and the demand priority for these 13 policies was finally listed. According to the priority theory, this paper only selects the forest reform policy, which ranks in the top five demands of forest farmers, as the main content of this paper. As shown in table 4, 121 household forest farmers listed the science and technology policy as the primary demand of forest reform policy, followed by the policy promoting forestry economy; in the second policy demand, 116 household forest farmers still chose Afforestation subsidy; in the third policy demand, the maximum number of occurrence was afforestation subsidy policy, a total of 82 forestry farmers listed afforestation subsidy policy as the third demand; In the fourth policy demand, the policy demand of forest farmers turned to science and technology services, a total of 87 times. In the fifth policy demand, the forestry rights mortgage loan was the most frequently selected, with a total of 81 times.

Table 4. Order of demand for Forestry Reform Policy.

\begin{tabular}{|c|c|c|c|c|c|c|}
\hline code & Forestry Reform Policy & No.1 & No.2 & No.3 & No.4 & No.5 \\
\hline 1 & speed up the right certification & 17 & 2 & 2 & 3 & 10 \\
\hline 2 & Standardize the contracting of large households & 3 & 3 & 1 & 2 & 4 \\
\hline 3 & Standardize joint household contracting & 4 & 2 & 4 & 2 & 12 \\
\hline 4 & Settlement of forest rights disputes & 17 & 6 & 12 & 18 & 9 \\
\hline 5 & Forestry rights mortgage loan & 44 & 33 & 40 & 59 & 81 \\
\hline 6 & Policy forest insurance & 41 & 74 & 51 & 12 & 33 \\
\hline 7 & Cooperative Organization for the Development of Forestry & 11 & 9 & 11 & 23 & 27 \\
\hline 9 & Standardize the circulation of forest land & 37 & 48 & 49 & 31 & 11 \\
\hline 10 & Science and technology service & 121 & 34 & 51 & 87 & 43 \\
\hline 11 & Subsidy for the upbringing of middle and young forests & 45 & 103 & 81 & 30 & 31 \\
\hline 12 & Ecological public welfare forest compensation & 20 & 61 & 77 & 41 & 9 \\
\hline 13 & Afforestation subsidy & 45 & 116 & 82 & 77 & 21 \\
\hline
\end{tabular}

It can be seen from table 4 that there is inconsistency in the order of the policy demand of forestry, agriculture and forestry reform. Therefore, it is difficult to carry out effective analysis. To achieve the purpose of this study, this paper will use the hierarchical clustering method to classify the needs of forest farmers for forest reform policies. In order to analyze the importance of different policies to forest farmers, and carry out hierarchical ranking. By using the Average Linkage [9], the forest reform policies can be grouped into four categories according to the priority of forest farmers demand for different policies. The specific stratification situation is as follows:

The first level is the subsidy policy category (equivalent to subsidies below). Including middle and young forest upbringing subsidy, ecological public welfare forest compensation and afforestation subsidy. In the policy demand priority clustering analysis chart, we can see that the ecological public welfare forest compensation and afforestation subsidies are obviously grouped into one category, and the frequency of the two policies in Table 4 is also relatively close to each other. In order to accurately analyze the demand priority of forest farmers, the two policies 
are sorted by referring to the method of weight transfer in this paper. [10] In contrast, the demand of forest farmers for afforestation subsidy policy should take precedence over the demand for ecological public welfare forest compensation policy.

The second level is the science and technology service policy (the following "science and technology" equivalent). As shown in the priority clustering analysis chart of forestry, agriculture and forestry reform policy, the science and technology service policy is grouped into one category separately. Combined with the number of times the science and technology service policy appears in each place in Table 1, this paper takes the science and technology service policy as the second level demand.

The third level is forestry financial policy (the following "finance" equals this). Including forest mortgage loans and policy forest insurance. In Table 4, compared with policy forest insurance, more households chose forest right mortgage loan as the most needed forest policy, while less households selected forest right mortgage loan as the second needed forest policy., The demand of forest farmers for forest right mortgage policy should take precedence over policy forest insurance from the table 4 .

The fourth level is other supporting policies for scale management (the following "other" is equivalent to this). These policies include speeding up the issuance of certificates, standardizing large household contracting, standardizing joint household contracting, resolving forest right disputes, developing forestry cooperative organizations and standardizing forest land circulation. According to the frequency of each policy in Table 4 and according to the method of transfer without authority, the strongest demand at the fourth level is to promote the development of forest economy, followed by standardizing forest land circulation, resolving forest right disputes, developing forestry cooperative organizations, standardizing joint household contracting and standardizing large household contracting.

\section{Analysis on the Influencing Factors of the Priority Order of Forest Farmers Demand for Forest Reform Policy}

\subsection{Model Construction}

In order to further analyze the influencing factors and degree of forest farmers demand for different forest reform policies, this paper uses empirical analysis method to study the influencing factors of forest farmers demand for forest reform policies. Through the previous cluster analysis of forest farmers demand priority for forest reform policy, forest farmers demand for forest reform policy was divided into four categories. In order to study the influencing factors of forest farmers demand priority order for different forest reform policies, this paper reconstructs the demand priority degree of forest farmers for forest reform policy. In the first place of policy demand, forest farmers choose middle and young forest upbringing subsidy, ecological public welfare forest compensation and afforestation subsidy, then the policy demand is assigned to 1 , forest farmers choose science and technology service in the first place of policy demand, and their policy demand is assigned to 2 . In the first place of policy demand, forest farmers choose forest right mortgage loan and policy forest insurance, and assign their policy demand to 3 . Forestry farmer chose other supporting policies of scale management in the first place of policy demand, so his policy demand was assigned a value of 4 . The definitions of dependent variables and independent variables are shown in Table 5.

Table 5. The definition of the variables involved in the model.

\begin{tabular}{|c|c|}
\hline Variable & Definition \\
\hline Policy demand & $\begin{array}{l}\text { Forest farmers demand for forest reform policy: } 1=\text { subsidy policy; } 2=\text { science and technology policy; } 3=\text { financial policy; } \\
4=\text { other supporting policies for scale management }\end{array}$ \\
\hline Sex & Sex of head of household: $1=$ male; $0=$ female \\
\hline Age & $\begin{array}{l}\text { Age of head of household: } 1=\text { under } 30 \text { years old; } 2=31 \sim 40 \text { years old; } 3=41 \sim 50 \text { years old; } 4=51 \sim 60 \text { years old; } 5=\text { over } \\
60 \text { years old }\end{array}$ \\
\hline Education & $\begin{array}{l}\text { Education level of head of household: } 1=\text { primary school and below; } 2=\text { junior high school; } 3=\text { senior high school; } 4= \\
\text { junior secondary school and above }\end{array}$ \\
\hline Occupation & $\begin{array}{l}\text { Occupation of head of household: } 1=\text { farming; } 2=\text { farming and working; } 3=\text { farming and sideline work; } 4=\text { long-term } \\
\text { migrant work; } 5=\text { fixed wage income; } 6=\text { other }\end{array}$ \\
\hline Cadres & Have family members ever served as cadres: $1=$ yes; $0=$ no \\
\hline Number & Number of family forest plots: $1=1 \sim 4 ; 2=5 \sim 10 ; 3=$ more than 10 \\
\hline area & Household forest land area: $1=1.33 \mathrm{hm} 2 ; 2=1.4 \sim 6.73 \mathrm{hm} 2 ; 3=6.73 \sim 13.3 \mathrm{hm} 2 ; 4=13.3 \mathrm{hm} 2$ \\
\hline Cooperation Organization & Whether or not to join the Forestry Cooperation Organization: $1=$ Yes; $0=$ No \\
\hline joint contracting & Whether to participate in joint contracting: $1=$ yes; $0=$ no \\
\hline Forest land circulation & Whether have a forest land circulation: $1=$ yes; $0=$ no \\
\hline loan against collateral & Whether have a mortgage for forest rights: $1=$ yes; $0=$ no \\
\hline forest insurance & Whether or not by the forest insurance: $1=$ yes; $0=$ no \\
\hline Construction of forest & Whether or not plant the forest in the last year: $1=$ yes; $0=$ no \\
\hline
\end{tabular}

According to the existing research results, this study defines the resource endowment as the factor of production, and draws lessons from Williamson theory of asset specificity [11], divides the resource endowment of forest farmers into 
capacity endowment, social resource endowment, forest land resource endowment and so on, and most of the policy demand depends on the difference of forest farmers resource endowment. Capacity endowment mainly examines the sex and age of the head of household. The age of forest households, especially the age of heads of household, has an important impact on the decision-making behavior of their families, and it is also the embodiment of a kind of ability. The longer the forest farmers engage in forestry management activities, the stronger the management decision-making ability. The social resource endowment mainly examines the educational level and social capital owned by forest farmers (this study is mainly based on whether the head of household is a village cadre or not). The higher the level of education or as village cadres, they have the stronger social capital endowment. The forest land resource endowment is reflected by the number of forest plots and forest land area occupied by forest households. The larger the forest land area is, the stronger the forest land resource endowment is. Because of the stronger forest land resource endowment, forest farmers are more likely to expand production, at the same time they are more sensitive to the price subsidy policy.

The demand of forest farmers can be subsidy policy, science and technology service policy, forestry financial policy and other supporting policies of scale management. Therefore, the multivariate Logistic model can be used for analysis in this paper, and the multivariate Logistic model is as follows:

$$
\ln [p(j) p(J)]=\alpha j+\sum \beta j k X K+\varepsilon
$$

In the formula: $\mathrm{J}$ denotes the occurrence ratio of forest farmers demand for forest reform policy; $p(j)$ to category $j$ policy demand, $\ln [\mathrm{p}(\mathrm{j}) / \mathrm{p}(\mathrm{J})]$ represents the natural logarithm of the ratio of a policy demand to a reference policy demand, $\alpha$ $\mathrm{j}$ is a constant term, and $\ln [\mathrm{p}(\mathrm{j})$ / policy] represents the natural logarithm of the ratio of a policy demand to a reference policy demand. $\beta \mathrm{jk}$ indicates the regression coefficient of $\mathrm{k}$ influencing factors of policy demand in item $\mathrm{j} . \beta \mathrm{jk}>0, \beta \mathrm{jk}<$ 0 and $\beta \mathrm{jk}=0$ indicate that the demand of this policy is stronger, weaker and no difference than that of reference policy, respectively. XK indicates the influencing factors of forest farmers demand for forest reform policy. $\varepsilon$ is random error.

\subsection{Analysis of Estimated Results}

Based on the investigation data of collective forest right system reform, the influencing factors of forest farmers demand priority for forest reform policy are estimated by Stata14. 0 software, and the regression results are shown in Table 6.

Table 6. Regression results of multivariate Logistic model for influencing factors of policy demand of forest farmers.

\begin{tabular}{|c|c|c|c|c|c|c|}
\hline Independent variable & Technology/subsidy & Finance/subsidy & Other/subsidy & Finance/technology & Other/technology & Other/finance \\
\hline age & -0.1500 & $-0.3253 * * *$ & -0.0483 & -0.1277 & 0.3840 & $0.7004 *$ \\
\hline $\operatorname{sex}$ & 0.2560 & -0.5094 & -0.1988 & -1.9343 & -0.4800 & 0.5702 \\
\hline education & 0.3631 & 0.2740 & 0.2173 & -0.108 & -0.1640 & -0.1546 \\
\hline occupation & -0.4110 & 0.052 & 0.2530 & 0.1319 & 0.1710 & 0.1631 \\
\hline crades & -0.3005 & -0.0578 & 0.6772 & 0.2664 & 0.2724 & 0.2609 \\
\hline the number of forestland & -0.2530 & -0.02786 & -0.0482 & 0.0056 & 0.0193 & -0.0182 \\
\hline Cooperative organization & 0.0247 & 1.2992 & -0.5152 & 0.6568 & -0.557 & -0.5482 \\
\hline Joint household contract & -0.3546 & $-0.5891 *$ & -0.8501 & -0.3680 & 0.5459 & 0.7162 \\
\hline the dispute of forest right & -0.2420 & -0.35662 & 0.720 & 0.1426 & 0.1653 & 0.8610 \\
\hline Forest land circulation & -0.3247 & 0.5253 & -1.4698 & 0.9740 & 0.9033 & -1.7170 \\
\hline Loan & $1.353 *$ & $1.1501 *$ & -0.3431 & -0.1540 & -1.719 & -1.4015 \\
\hline Forest insurance & 0.2896 & 0.3393 & 0.0128 & -0.4345 & -0.2353 & 0.1304 \\
\hline Construction of forest & $0.7858 * *$ & 0.2292 & 0.0671 & -0.1230 & -1.3431 & -0.6784 \\
\hline Pseudo R2 & 0.0828 & & & & & \\
\hline
\end{tabular}

*, * and * indicated that the statistical test was significant at the levels of $10 \%, 5 \%$ and $1 \%$, respectively.

In the results of regression model, the chi-square test value of the model is 44.47 , and $\mathrm{P}<0.05$, which indicates that the independent variables selected by the regression model have a certain ability to explain the influencing factors of policy demand, and the priority of forest farmers demand for forest reform policy with different resource endowment is shown in Table 7.

Table 7. Priority of Forest Farmers Policy demand.

\begin{tabular}{lllll}
\hline $\begin{array}{l}\text { Characteristics of forest } \\
\text { farmers }\end{array}$ & NO.1 & NO.2 & NO.3 & NO.4 \\
\hline age & subsidy policy & other policies & Science and Technology & financial policy \\
sex & Science and Technology Policy & subsidy policy & Policy & financial policy \\
education & Science and Technology Policy & financial policy & other policies & subsidy policy \\
occupation & other policies & financial policy & subsidy policy & Science and Technology Policy \\
crades & other policies & subsidy policy & financial policy & Science and Technology Policy \\
\hline
\end{tabular}




\begin{tabular}{|c|c|c|c|c|}
\hline $\begin{array}{l}\text { Characteristics of forest } \\
\text { farmers }\end{array}$ & NO.1 & NO.2 & NO.3 & NO.4 \\
\hline the number of forestland & subsidy policy & financial policy & other policies & Science and Technology Policy \\
\hline the area of forestland & financial policy & Science and Technology Policy & other policies & subsidy policy \\
\hline Cooperative organization & financial policy & Science and Technology Policy & subsidy policy & other policies \\
\hline Joint household contract & subsidy policy & other policies & $\begin{array}{l}\text { Science and Technology } \\
\text { Policy }\end{array}$ & financial policy \\
\hline the dispute of forest right & other policies & subsidy policy & financial policy & Science and Technology Policy \\
\hline Forest land circulation & financial policy & subsidy policy & other policies & Science and Technology Policy \\
\hline Loan & Science and Technology Policy & financial policy & subsidy policy & other policies \\
\hline Forest insurance & Science and Technology Policy & other policies & financial policy & subsidy policy \\
\hline Construction of forest & Science and Technology Policy & financial policy & other policies & subsidy policy \\
\hline
\end{tabular}

From tables 6 and 7, the priority factors affecting the demand of forest farmers for forest reform policies are as follows:

(1) Among the characteristics of forest farmers, the age of heads of household significantly affected the demand of forest farmers for forest reform policies. The results show that the older the forest farmers are, the stronger the demand for subsidy policy is, and the stronger the demand for forestry financial policy is, the weaker the demand for forestry financial policy is. The reason may be that the older the forest farmers are, the more they pay attention to the immediate benefits they can get, and subsidies can directly increase the income levels of forest farmers. In the investigation, it was found that the policy demand of forest farmers for forest right mortgage loans was not strong, mainly based on the long forestry production cycle after obtaining loans for reinvestment, and its income is very unstable, which increases the pressure on forest farmers to repay loans. Although the gender, education level and occupation of the head of household have not passed the significance test, they still affect their demand for forest reform policy. The higher the education level of the head of household, the more we can see the role of science and technology service in promoting forestry development. The demand for forestry science and technology service policy and forestry financial policy is stronger, while the demand for other policies is stronger for forest farmers with agriculture as the main occupation.

(2) Among the characteristics of forest resources, the area of household forest land significantly affects the demand of forest farmers for forest reform policy. The larger the area of forest land, the stronger the demand for financial policy and science and technology policy, but the weaker the demand for subsidy policy. With the gradual expansion of forest land area, forestry investment of forest farmers is increasing. Forest farmers are eager to solve the forestry capital investment in the process of forestry development, and improve the level of forestry output through the application of forestry science and technology services. Although the number of family members who have served as village cadres and family forest plots has not passed the significant test, it still affects the demand of forest farmers for forest reform policy. As a bridge between policy and forest farmers, village cadres have played an indispensable role in grass-roots service organizations. Some family members have served as village cadres. They have a better understanding of the significance of the implementation of the reform policy of collective forest rights system, and can better see the guiding role of the policy, and have a strong demand for other forest reform policies for supporting management. The larger the number of forest plots does not mean that the forest land resources are more abundant. Under the limited forest land area, the more forest land blocks are, the higher the degree of forest land fragmentation is. The fragmentation of forest farmers makes it difficult for forest farmers to give full play to the benefits of scale management, which hampers the forestry investment enthusiasm of forest farmers. The demand for subsidy policy should take precedence over financial policies and other policies and science and technology policies of supporting management.

(3) Among the behavior characteristics of forest farmers, forest farmers have handled mortgage loans for forest rights, participated in forest insurance and carried out forest construction with the strongest demand for science and technology policy. Forest farmers who have applied for forest right mortgage loans and forest construction have significantly affected their demand for forestry science and technology service policy. Obtaining funds through forest right mortgage loan and carrying out afforestation can increase the scale of forestry management. With the expansion of management scale, simple factor investment is difficult to meet the needs of forest farmers and forestry production. Therefore, forest farmers urgently need to improve the application of forestry science and technology services, with science and technology as the forerunner. As the primary productive force, the development of swing science and technology realizes the long-term income and efficiency of forestry production. With more and more forest farmers joining the forestry cooperative organization, the financial and technical problems restrict the development of the forestry cooperative organization. The forest farmers who have joined the cooperative 
organization hope to strengthen the support of forestry financial policy and forestry science and technology policy. The forest farmers participating in the joint household contract accounted for only $7 \%$ of the total sample, and they were basically brothers and sisters with the family as the management unit. The joint household contracting did not bear fruit, and the primary policy demand of this part of the forest farmers was the subsidy policy. Raise the intensity of subsidies, followed by other supporting reform policies. Forest farmers who have had forest right disputes should take precedence over forestry subsidies for other supporting policies of scale management. Forestry finance and forestry science and technology. In the case of forest right disputes, the primary policy demand of forest farmers is to speed up the settlement of forest right disputes and certify their forest land rights, and only by constantly defining property rights can the basic interests be protected more effectively.

\section{Conclusion}

It can be found that the priority order of policy demand for forest farmers with different resource contributions is different, and the macroscopic implications for us is that the key direction and supply form of forest reform policies should be changed, and the traditional policy-oriented policy formulation procedure with supply as the demand as the leading policy formulation, or, the market-oriented concept is to promote the policy supply.

The main policy of forest reform, that is, clear property rights, has been basically completed, and the next step should focus on promoting the supporting reform and reform policy with stronger demand from forest farmers. According to the results of the study, we believe that at present, we should focus on the following three policies: first, we should continue to implement and increase subsidies for forestry and forestry, improve the enthusiasm of forestry and forestry, and ensure the income expectations of forest farmers; Second, give full play to the contribution of science and technology to forestry production, improve the efficiency of forestry production from a macro point of view, reduce the input cost of factors of production of forest farmers from a micro point of view, in order to improve the economic income expectations of forest farmers; Third, we should focus on promoting supporting reforms, promoting forest right mortgage loans, policy-oriented forest insurance policies and building forest rights trading centers to promote the capitalization and optimal allocation of forestry capital sources, so as to achieve the long-term development of the forestry industry.

\section{Acknowledgements}

This work was supported by the National Natural Science Foundation of China (Grant No.41701622), the Major Program of China's State Forestry Administration (Grant No.JYC2019-76). The contents of this paper are solely the responsibility of the authors and do not represents the official views of the aforementioned institutes and funding agencies.

\section{References}

[1] Decision of the CPC Central Committee and the State Council on speeding up Forestry Development [EB/OL] (2003-09-11) [2013-12-02]

http://news.xinhuanet.com/zhengfu/2003-09/11/content10750 42.htm

[2] ShiWuxiang, Chongsuvivatwong The influence of the rural health security schemes on health utilization and household impoverishment in rural China: data from a household survey of western and central China [J]. International Journal for Equity in Health, 2010, 9 (1).

[3] John Herbert Ainembabazi, Arild Angelsen. Do commercial forest plantations reduce pressure on natural forests? Evidence from forest policy reforms in Uganda [J]. Forest Policy and Economics, 2014, 40.

[4] Oyvind Nystad Handberg, Arild Angelsen. Pay little, get little; pay more, get a little more: A framed forest experiment in Tanzania [J]. Ecological Economics, 2016.

[5] Rebecca A. Efroymson, Keith L. Kline, Arild Angelsen, Peter H. Verburg, Virginia H. Dale, Johannes W. A. Langeveld, Allen McBride. A causal analysis framework for land-use change and the potential role of bio-energy policy [J]. Land Use Policy, 2016, 59.

[6] Arild Angelsen. Agricultural expansion and deforestation: modelling the impact of population, market forces and property rights [J]. Journal of Development Economics, 1999, 58 (1).

[7] Liu Zhenbin, The analysis of the change of the scale of the forest land after the reform of the collective forest right system based on the empirical study of the typical sample village in fujian [j]. Rural Economy, 2016 (01): 44-49.

[8] Felipe Arias Fogliano de Souza Cunha, Jan Börner, Sven Wunder, Carlos Alberto Nunes Cosenza, André F. P. Lucena. The implementation costs of forest conservation policies in Brazil [J]. Ecological Economics, 2016, 130.

[9] Belcher B, Achdiawan R, Dewi S. Forest-Based Livelihoods Strategies Conditioned by Market Remoteness and Forest Proximity in Jharkhand, India [J]. World Development, 2015, 66: 269-279.

[10] Lawrence Hammerton. Statistical analysis with STATA [M]. Guo Zhigang, translated. Chongqing: Chongqing University Press, 2011: 293-297.

[11] Guangping Miao, R. A. Chinese Collective Forestlands: Contributions and Constraints. West. International Forestry Review. 2004. 